\title{
The Functions of Rare Books
}

Mr. Powell is in the Accessions Department of the University of California $\mathrm{Li}$ brary at Los Angeles.

W

HEN I asked Christopher Morley what he thought was the function of rare books, he replied, "Surely this is no more answerable than what is the function of ruined castles, or clumps of birch trees, or vintage wines, or amethysts. The function of rare books, we guess, is to be rare; to give a highly technical, specialized and associative pleasure to those susceptible thereto."

A writer recently returned from Spain gave me a different answer. "The function of rare books," he said, "is to form barricades in the streets. Thick old folios and quartos, with their tough rag paper and skin-covered boards, are admirable deflectors of machine-gun fire and shrapnel."

According to Randolph G. Adams, when President Roosevelt called some American librarians together to explain to them and to ask their help about the proposed library at Hyde Park, he openly said that the future seemed to him so ominous that he believed collections of rare books should be established outside of the metropolitan areas, in sections less open to bombing raids.

As long ago as 1929, upon learning of the narrow escapes of the Public Records Office from destruction by Zeppelin bombs in the last war, the Albany and Troy alumni of the University of Michigan provided a fund, the interest of which was to be used for the purchase of photostats of documents relating to the early history of the American colonies preserved in the Public Records Office in London.

We are obviously living in a perilous age, threatened on one hand by the danger of war, and on the other by a domestic economy which forces libraries to operate with the utmost frugality. So desperate have many librarians become in their effort to meet bare operating expenses that they tend to be irritable at even the mention of rare books. "Rare books!" said the head of one large university library, "we have little time for them. We are too busy being a functional research library." In a young giant of a western library the card catalog, like one of those Fourth of July pyrotechnic pills which when ignited grows to fabulous dimensions, has crowded out the exhibit cases where the library was wont to display its rare books. The monster has been cut in two, not to halt its growth, but to make it easier to consult.

Of course the librarian must be a hardheaded business man and know how to make ends meet. Nevertheless, this cold and efficient head should be accompanied by a heart warm with sentiment for the extraordinary. That is not an impossible ideal. Contrary to popular belief, vision and efficiency are not incompatible.

Rare books have a function; they can be made to serve no less than the battered texts in the reserve book room. A librarian who would minimize rare books to 
the point of exclusion in his so-called functional library, is merely revealing his own unfamiliarity with certain practical functions which can be served by rare books.

How does a library go about acquiring rare books, and what does it do with them after it gets them?

"If you would reason with me," said Voltaire, "you must first define your terms." By the term "rare book" I mean something rather special; some quality of age, or scarcity, or research significance, or beauty, or association, that sets a book apart from its fellows. It need not be an old book. When a book comes to a library, the first question to be asked is this: "Is the book rare, or even potentially rare?" The correctness with which the question is answered is a fairly accurate measure of the taste, discrimination, and scholarship of the official who decides. In this paper I have sometimes used the term "rare books" as almost synonymous with "special collections."

Rare books may be secured either by purchase or gift, or better yet by a combination of both. Let a library initiate a program based on the extension of its outstanding holdings; let it be known that it is spending what it can spare, to add just a bit more than "bread and butter" to the collection and help will come to it from the most unexpected sources. As Nathan van Patten once wrote me, "Whether or not a small library should purchase rare books is largely determined by its means. Whether or not a small library should seek and care for gifts of rare books depends upon the intelligence of its librarian and his associates."

\section{Avoid the Obvious}

In planning a program, the important thing for the small library to do is to avoid the obvious things to be found in every general collection of rare books. If, for example, a college in Los Angeles should concentrate on material concerning Los Angeles, it would be performing a far greater service to scholarship and to itself in the future than to have a feeble imitation of the nearby Huntington Library. In Los Angeles, we have an example of a small college library making a logical specialization, by collecting the works of its most distinguished literary alumnusI refer to the Robinson Jeffers collection at Occidental. As soon as news spread of this plan, which was initiated by the college itself, one of the west's noblest gentlemen stepped forward and gave his entire Jeffers library, the most extensive in existence. It is now very properly known as the Albert M. Bender collection. Another example of intelligent specialization is at Claremont College, where Willis Kerr is collecting local material relating to that natural element, the introduction of which turned a great region from desert to garden-a collection on the water supply of southern California.

The important thing is for the library to take the initiative, even though on a small scale, and not wait empty-handed for benefactors to come along. They will come, no doubt of it, to where they are drawn by kindred interests. Of the treasure room which he inaugurated at Northwestern, Theodore W. Koch writes, "It proves a very effective magnet to attract gifts."

In his address at the dedication of the Stockwell Memorial Library at Albion College, Randolph G. Adams said, "I feel the college library, as such, has the definite function of properly preserving books of especial and appropriate interest, as well as supplying books for ordinary readers 
and reading. Moreover, college libraries, depending as so many of them do upon gifts rather than on the appropriation of tax moneys, have to do something to show themselves worthy of such gifts. More and more friends and alumni of colleges are collecting books of which they will ultimately wish to dispose. Time and again, I have heard such book collectors express a desire to give books to libraries, but have recoiled from the idea because so many librarians have so little conception of the function of the collector and are not well trained in the treatment of unusual books."

I should like to ask, What library school is giving a course which would help overcome these objections raised by $\mathrm{Dr}$. Adams? Why not a course in collectors and collecting? It, among other things, would show, by an historical survey, the part played by private book collectors in the growth of American libraries. And I do not mean "book selection."

\section{McGregor Plan}

I spoke of the combination of purchase and gift as being the ideal way to carry out a rare book program. A few years ago there was established under the auspices of the American Historical Association, a practical scheme which combines these two methods; this is the McGregor plan for the encouragement of book collecting by American college libraries. The late Tracy W. McGregor devoted his life and wealth to active social service. It seems to have been his thought that there are those who are hungry for books; that if you can give a man a thought or an idea, it may be as important as giving him a square meal, or a new suit of clothes. Often, during the past thirty years, he could have been found of an evening in a mission in Detroit, reading aloud to derelict men, chapters or poems from his favorite books. What is more important, the unfortunates were listening.

In January 1933, Mr. McGregor wrote to Charles A. Beard, president that year of the American Historical Association, and outlined a plan for bibliographic philanthropy. What he proposed is best stated in his own words:

Through a friend of history, the Committee on Americana for College Libraries of the American Historical Association, has funds available to assist from ten to twenty institutions in purchasing rare source books in American history, commonly called Americana. The committee has decided to offer five hundred dollars per year for this purpose to each of certain colleges, providing the college will itself appropriate an equal amount, thus making one thousand dollars per year for each institution. The plan should be entered into with the expectation of continuing for a period of ten years or longer. ...

In the main, it is expected that a college will not take its own five hundred dollars from the sum annually appropriated to the librarian of the college for ordinary purposes, but will provide that sum in addition thereto. All books acquired through the plan are to be regarded and treated as rare books. That is to say, they shall not go into the stacks of the participating library, but into its treasure room, rare book room, or equivalent section, even if that be only a locked case in the librarian's office.

In selecting the colleges to benefit under the plan, the committee illustrated my point that to receive philanthropic blessings, a library needs to have shown itself worthy. The committee asks that the president, librarian, professors of American history, and chairman of the library 
committee are persons who have an appreciation of the sentimental, inspirational, and aesthetic values of books. Mr. McGregor was a book collector and bibliophile, and it was this, quite as much as his interest in literature as such, that led him to establish the plan. Libraries where either the librarian or the faculty are inclined to regard book loving with either skepticism or scorn, are not likely to be interested in the plan.

The committee has favored colleges in sections of the country not now so well supplied with rare Americana, rather than institutions in the great metropolitan centers which already have extensive collections. The aim is to develop provincial centers of culture, in an effort to counteract the centralizing tendencies of modern life. These are the colleges which are now participating in the McGregor plan:

Albion College, Albion, Michigan

Allegheny College, Meadville, Pennsylvania

Baylor University, Waco, Texas

Birmingham-Southern College, Birmingham, Alabama

Carleton College, Northfield, Minnesota

College of William and Mary, Williamsburg, Virginia

Dartmouth College, Hanover, New Hampshire

Emory University, Atlanta, Georgia

Florida State College for Women, Tallahassee, Florida

Mills College, Oakland, California

Mount Holyoke College, South Hadley,

Massachusetts

Pomona College, Claremont, California

Wake Forest College, Wake Forest, North Carolina

Wesleyan College, Macon, Georgia

Western Kentucky State Teachers College, Bowling Green, Kentucky

College of Wooster, Wooster, Ohio

It would of course be foolish to concentrate on rare books at the expense of the library's regular program. But I believe that this talk of bread and butter (meaning the "necessities") versus cake (i.e. rare books) is becoming hackneyed. Besides, who wants to live on bread and butter alone? If the French eat more bread than any other people in the world, they also drink the finest wines, and finish their meals with fruit. There is such a thing as a balanced diet. And calling unusual, fine, and beautiful books "cake" is uncritical. The college library which does no more than serve as a place to dig up facts is merely a storehouse. That taste and understanding can be taught in the library as well as in the classroom is being proved in such progressive institutions as Stephens College. Rare books are (permit me a paradox) a necessary luxury. Perhaps the average budget balancer's suspicion of them can be traced to the fact that too often rare books are allowed to live a sort of hallowed, touch-me-not, existence. If we should not circulate them carelessly, neither should we hoard them from sight and touch. There are ways to make rare books pay for themselves-and this leads to another question.

\section{Uses of Rare Books}

Now that we have them, what are we going to do with our rare books? First of all, a quotation from a recent article by Harvie Branscomb, director of libraries at Duke University, who has just completed a survey of college libraries for the Association of American Colleges:

We have been going through a period of vast accumulation of library materials. This has created acute problems in connection with the organization and handling of these materials. During the same period the profession of librarianship has arisen, and as book collections have grown, the colleges 
have employed trained librarians. It is not surprising, therefore, that due both to previous training and to the pressure of immediate problems, technical procedures rather than educational ends have occupied the primary attention of college and university librarians.

This has had several unfortunate consequences. The first is that librarians have been taken at their own rating and conceived of as technicians rather than as educators. The gap between the library staff and the faculty, of which the former are keenly conscious, has been an inevitable one.

I have used these words to preface the section of this paper dealing with some uses of rare books, for I believe that rare and fine books can play an important role in closing the gap between staff and faculty. From them can be forged strong chains of sentiment with which to bind together librarians, faculty, students, and alumni.

That this was one of the purposes of the McGregor plan is clear from the words of the committee:

We expect the colleges to formulate and put into execution a plan for careful and appreciative use of the books by undergraduate as well as graduate students, through the teacher of American history or other appropriate person, so that the books may not be put away merely to remain dead and forgotten as museum pieces.

Milton observed that books are not dead things. My observation is that often their custodians are. Because of their historical significance, their intrinsic value, their beauty, and sentimental associations, rare books, when intelligently grouped, have power to excite the imagination and stimulate the intellectual curiosity of the student. A rare book collection, no matter how modest, can be made by alert librarians to play an educational role, and to enliven the library, increase its prestige, and to draw alumni and friends. Whereas the rare book collection in a university library is primarily for research, the smaller the institution the more potent can become rare books in directly influencing the students. The collection can be made to work through exhibits and catalogs, and by class consultations involving students, professors, and librarians, and by special courses given by the library staff in bibliography, book arts, etc. There is St. John's College at Annapolis whose entire curriculum is based on an intensive study of one hundred great books.

\section{Chapin Collection at Williams}

One of the most intrinsically valuable college rare book collections in this country is also one of the most active and functional, the Chapin Library at Williams College. The last report of the custodian, Lucy Osborne, should be read by every one who is skeptical of putting rare books to work. For ten years Miss Osborne has given a course "The History of the Printed Book," the purpose of which in part is to "dispel from the undergraduate mind some of the mists obscuring the subject of rare books, and particularly of early printing; to show the origin in the fifteenth century of bookmaking terms and practices current today."

According to Miss Osborne, the most concrete advance made in fifteen years is the use of the Chapin Library by classes. She maintains that there is a peculiar link forged between the rare material and the student, when, very soon after a classroom lecture, he sees the books at close range and hears the instructor relate the points made in the lecture, to the Chapin item. For the past three years certain classes in art and English have been held regularly in the Chapin study. Other faculty mem- 
bers have brought classes to discuss the current exhibit which has been arranged for this purpose.

I can hear some of the college librarians thinking aloud, "Oh, it would be easy if we only had a collection like the one at Williams-twelve thousand choice items, in a special building, with a custodian and assistants!" $\mathrm{My}$ answer is, great collections from thin pamphlets grow. Get busy with whatever you have, even though it be only one row of books in an office case.

Again John Milton on books: "I know they are as lively, and as vigorously productive, as those fabulous dragon's teeth; and, being sown up and down, may chance to spring up. ..." Not "armed men," I maintain, but more books. Sow a few books up and down your corridors on appropriate occasions, and watch them multiply. Do not wait for that "angel" to provide you with a sumptuous, endowed collection. Put whatever you have to work. Is it shocking to confess that if it were not for the scholarly publicity given the Hardy collection at Colby and the Browning at Baylor, I would never have heard of those two institutions?

The centenary exhibition of one hundred American first editions paralleling the growth of the college, arranged by Flora B. Ludington at Mount Holyoke, is an example of intelligent and discriminating cooperation of librarian and faculty. The annotations were written by both of them, and the catalog crowned with a foreword by Van Wyck Brooks. The hand-lists of exhibitions at the Clements Library of the University of Michigan are little gems.

\section{Scripps Collection}

Crossing the continent to southern Cali- fornia, rare books may be seen at work in the library at Scripps College. The librarian, Dorothy Drake, writes that they are concentrating on fine printing, and that every book added is for historical and research reasons rather than as a museum piece. Also at Scripps is the MacPherson collection of books by and about women, which through a yearly allowance by the donor, is becoming an outstanding research collection. Its purpose is to reveal the contributions and personalities of women in all periods of history.

At Mills College across the bay in Oakland we find another example of an active rare book collection. Under the curatorship of Mrs. Louise F. Barr, the Bender collection of fine books and manuscripts has grown each year through the generosity of $\mathrm{Mr}$. Bender from a modest beginning to a present total of three thousand items. It is the generative nucleus out of which has evolved a students' Bibliophile Society. The society and the curator recently combined to produce a notable catalog of thirty books and manuscripts from the Albert $M$. Bender collection.

I have already spoken of $\mathrm{Mr}$. Bender in connection with the Jeffers collection which he gave to Occidental College. Scripps, Berkeley, Stanford, and Trinity College in Dublin also know him as an incomparable patron. I do not wish to overload that lovable man, but I am sure that if Fresno State College were to announce that it had commenced a William Saroyan collection, it would not be long before they heard from Mr. Bender. And the same goes for Salinas Junior College and John Steinbeck.

Collecting in contemporary fields, especially the works of living authors, can be especially profitable when an institu- 
tion concentrates on its own alumni writers. Through its Friends of the Library group known as the Yale University Library Associates, that institution has assembled magnificent collections of the books and manuscripts of Archibald MacLeish and Sinclair Lewis, and, apart from its own alumni, has acquired the great George T. Keating Conrad library, and unique Thomas Mann and Edith Wharton collections. They have even poached on Harvard with a T. S. Eliot exhibit, for which Donald C. Gallup wrote an excellent catalog.

\section{Funds Not of First Importance}

Funds are not the important thing in collecting a contemporary's works and memorabilia; what is necessary is vision, courage, discrimination, and enthusiasm. It pains me to think of Emily Dickinson and Herman Melville having had to wait until the next century after them for any widespread recognition. "Surely," one says, "you do not hold our librarian predecessors responsible for that! Literary discovery and popularization are the proper function of critics, not librarians." "Very well then," I reply, "you would have librarians remain mere custodians, technicians and administrators. It is true that that is what we have largely been in the past. Now there must be a new vision, or we will perish. And there is a new vision taking form out of the searching scrutinies to which we are subjecting our profession. This gives me confidence in our future."

The classics of tomorrow can be created at no other time than today. Scholars of the future will thank the librarians of the present who had the vision to accumulate exhaustive collections of material dealing with their outstanding creative contemporaries. Rather than competing vainly with the rich university library in amassing collections of ancient and expensive rarities, the college library might well concentrate on the contemporary field. They would find it both inexpensive and exciting.

Finally, I would not have you carry away an impression of intellectual snobbism as concomitants of a rare book collection. Rare books are something special, but they are not necessarily incongruous in a democratic culture. This is a swift and dangerous time in which we live. Museums are being emptied of people who run into the streets at the sound of droning overhead. If you have rare and fine books, see that they are working for you, lest they be swept away in the streamlined flow of this age. Regard them for what they will $d o$ for you. Otherwise they have no meaning. 